\title{
Mellom samfunnsstrukturer og profesjon: om avgrensning, kultivering og premisser for adekvat skjonnsutovelse i legerollen
}

\author{
Kristine Bærøe
}

Denne artikkelen tar utgangspunkt $i$ et skille mellom samfunnsstrukturer som avgrenser legers skjønnsmessige utfoldelse på den ene siden, og profesjonens tilrettelegging for kultiveringen av erkjennelsesmessige ferdigheter $p a ̊$ den annen. Ved å videreføre $H$. Grimen og A. Molanders anvendelse av S.E. Toulmins modell for praktisk resonnering i en klinisk kontekst redegjør jeg for legeskjønnets multidimensjonale, epistemiske struktur. Gjennomgangen viser hvordan skjønnsanvendelse i legerollen kan analyseres $i$ henhold til en fagteknisk, en distributiv og en relasjonell dimensjon. Mot denne bakgrunnen diskuterer jeg så spenninger som oppstår i skjoringspunktet mellom strukturering og kultivering av skjønnets ulike dimensjoner. Diskusjonen tydeliggjør at den medisinske profesjonen ikke kan betraktes som en selvtilstrekkelig premissleverandør når det gjelder ̊̊ sikre adekvat kultivering av medlemmenes skjønnsutøvelse $i$ en klinisk kontekst. Ved å synliggjøre og vektlegge de relevante profesjonseksterne bidragene i profesjonens pågående selvregulering kan befolkningens berettigete tillit til profesjonen styrkes ytterligere.

Nøkkelord: strukturelt skjønn, epistemisk skjønn, profesjon, selvregulering, tillit

English summary: In Between Structures of Society and Profession:

On Delimitation, Cultivation and Premises for Adequately Exercising Judgment in the Role as Physician

The point of departure of this article is a distinction between societal structures that delimit the discretion of the physician on the one hand and the profession's arrangements for the cultivation of the physician's judgment on the other. By developing H. Grimen and A. Molander's application of S.E.

Kristine Bærøe, Etikkprogrammet, Universitetet i Oslo Kristine.Baroe@ ifikk.uio.no 
Toulmin's model for practical reasoning in a clinical context, the multidimensional epistemic structure of the physician's judgment in terms of technical, distributive, and relational judgment is accounted for. Against this backdrop, tensions emerging in the intersection between delimitation and cultivation of professional judgment in its various dimensions are discussed. The discussion clarifies that the medical profession is not a self-sufficient provider when it comes to ensuring an adequate cultivation of its members' judgment in a clinical context. It is argued that by emphasising and implementing the relevant external contributions to the profession's ongoing self-regulation, the public's justified trust in the medical profession can be strengthened.

Keywords: discretion, judgment, profession, self-regulation, trust

\section{Innledning}

Når vi snakker om «skjønn» i tilknytning til personer eller grupper som innehar en samfunnsfunksjon, brukes «skjønn» $\mathrm{i}$ to forskjellige betydninger. På den ene siden forstås skjønn som en erkjennelsesaktivitet som pågår når vi forsøker å skjelne mellom handlinger som riktige eller gale, vurderer kvaliteten ved estetiske objekter og lignende, men uten fastlagte standarder for vurderingene. Denne versjonen av «skjønn» kaller H. Grimen og A. Molander «epistemisk skjønn» («judgment» på engelsk) (Grimen \& Molander 2008).

På den annen side brukes «skjønn» om det Grimen og Molander kaller «strukturelt skjønn» («discretion» på engelsk). «Strukturelt skjønn»skal forstås som et handlingsrom for beslutninger som ikke på forhånd er underlagt gitte standarder. R. Dworkin understreker at strukturelt skjønn forutsetter at beslutninger normalt er underlagt begrensinger som er pålagt en av andre autoriteter enn aktøren selv (Dworkin 1978). Sagt på en annen måte beskriver strukturelt skjønn det området man har skjønnsmyndighet over i en ellers regulert virksomhet. Dette visualiserer Dworkin ved å sammenligne strukturelt skjønn med «hullet i en smultring». Tilsvarende beskriver R.E. Goodin dette skjønnet som «en lakune i et system av regler» (Goodin 1986). Det åpne rommet representerer den relative friheten til å kunne velge hvordan man skal handle eller vurdere en situasjon ved å bruke ens egne uavhengige standarder for begrunnelse.

Goodin, som er opptatt av strukturelt skjønn i forbindelse med distribusjonen av sosiale goder i en velferdsstat, gir en detaljert analyse av ulike varianter av strukturelt skjønn. Ifølge Goodin kan en persons strukturelle skjønn kategoriseres som ulike typer avhengig av hvorvidt beslutningene er begrenset av regler, hvor bindende disse reglene er, og hvorvidt personens beslutninger vil bli vurdert og potensielt overstyrt av andre ansatte. 
Videre er det viktig å understreke at strukturelt skjønn må relateres til at det er delegert, og ikke noe man bare har eller tar. Strukturelt skjønn betegner en delegert autoritet som er relativ til andre autoriteter innenfor et system av beslutningsmakt, og vi kaller strukturelt skjønn da også «skjønnsmyndighet».

\section{Forholdet mellom strukturelt skjønn og epistemisk skjønn}

En plausibel måte å knytte strukturelt og epistemisk skjønn sammen på vil være å si at når noen er delegert skjønnsmyndighet, så er de også forventet å utføre sine oppgaver på måter man anser som rimelige (Molander \& Grimen 2010). Skal skjønnsutøvelsen inngi tillit, må den naturligvis også fremstå som rimelig for andre enn skjønnsutøveren selv. Forventningen om god skjønnsutøvelse retter seg mot den medisinske profesjonen på et gruppenivå, der profesjonen blir tilgodesett med vide skjønnmessige fullmakter. Samtidig retter den seg mot den enkelte lege og dennes tilkjente strukturelle skjønn på individnivå.

To avgjørende spørsmål blir dermed: Hvordan bør leger utøve sitt epistemiske skjønn i henhold til forventningen om at det vil resultere i gode og rimelige beslutninger? Og hvilke forordninger må være på plass for at resten av samfunnet skal ha en berettiget tillit til legers skjønnsbruk? Disse spørsmålene vil jeg forsøke å besvare i denne artikkelen. For å kunne nærme meg en konklusjon kreves en klargjøring av hvordan det spesifikke legeskjønnet avgrenses strukturelt og kultiveres profesjonelt, samt en nyansert analyse av det profesjonelle skjønnets virkeområde, formål og ressurser.

Dette er den videre gangen i presentasjonen: Jeg starter med å klargjøre hvordan strukturelt skjønn knyttet til legerollen avgrenses av ulike systemer, og hvordan skjønnet kultiveres gjennom profesjonsinterne reguleringer. Deretter gir jeg en presentasjon av skjønnets epistemiske funksjon basert på Grimen og Molanders utlegning av S.E. Toulmins modell for praktisk resonnering. Jeg videreutvikler så Molander og Grimens analyse av klinisk skjønn med kurativt formål til å gjelde en mer omfattende analyse av epistemisk skjønn i legerollen forstått i henhold til en fagteknisk, distributiv og relasjonell dimensjon. Mot denne bakgrunnen blir det så meningsfylt å diskutere spesifikke betingelser for utvikling av legenes profesjonelle skjønn, og spesielt betingelser som samtidig rettferdiggjør andres tillit til legenes skjønnsbaserte virke. 


\section{Strukturering av skjonn i legerollen fra et samfunnsperspektiv}

Avgrensning av legenes strukturelle skjønn fra et samfunnsperspektiv utgjør rammene for den epistemiske, skjønnsmessige aktiviteten. Det er derfor naturlig å ta utgangspunkt i en kartlegging av hvordan legenes skjønnsmyndighet avgrenses. Denne innskrenkningen skjer både i henhold til et profesjons- (gruppe-) og individnivå.

\section{Strukturering av skjonn i legerollen på et profesjonsnivå}

De ytre grensene for det strukturelle skjønnet på profesjonsnivå settes gjennom samfunnets regulering og overvåking av profesjonens virke gjennom ulike former for styringssystemer. Dette vil involvere all form for helsehjelpsrelaterte, eksternt pålagte lovreguleringer som direkte eller indirekte retter seg mot legenes virksomhet, og som innsnevrer rommet profesjonen har til å sette egne standarder for sin praksis. Eksempler vil være lov om foreskrivning av medikamenter, blåreseptordninger og ventetidsgarantier. Ulike mer eller mindre integrerte systemer av lover og regler vil i så måte omslutte det vi gjerne kaller den profesjonelle autonomi. Men også andre styringssystemer vil kunne bidra til å begrense profesjonens autonomi; rettssystemet som overprøvende instans og økonomiske systemer med krav om budsjettmessig tilpasning.

\section{Strukturering av skjonn i legerollen på et individnivå}

All individbasert medisinsk aktivitet som blir overvåket av myndighetene som kan vedta en eller annen form for represalier, reduserer den enkeltes profesjonelle autonomi. I tillegg vil også graden av individuell frihet den enkelte lege har, også struktureres av ulike organisatoriske forhold, som formålet med den spesialiserte tjenesten man tilbyr, hierarkiske stillingsstrukturer og fastsatte behandlingsrutiner.

\section{Kultivering av skjonn i legerollen fra et profesjonsperspektiv}

For å få et bedre grep på hva som ligger i profesjonsperspektiv i denne sammenhengen, trenger vi en nærmere avklaring av hva som ligger i begrepet «profesjon» og profesjonens forhold til samfunnet for øvrig. 


\section{Samfunnskontrakten}

«Profesjon» kan man forsøke å beskrive ved hjelp av karakteristikker som kjennetegner en profesjon, og som samtidig gjør det mulig å skille en profesjon fra andre former for virksomheter. Dette har det vært gjort mange forsøk på uten at man har klart å enes om en generell definisjon. Mange har dermed gitt opp dette prosjektet (Fauske 2008). «Profesjon» har samtidig en evaluerende betydning. Denne betydningen er knyttet til et ideal om medisinsk profesjonalisme som vektlegger implikasjonene av at profesjonen nyter stor grad av frihet, eller autonomi, i sitt virke. «Profesjonell autonomi» kan beskrives som den delegerte, autoritative myndigheten profesjoner tilkjennes gjennom en samfunnskontrakt (Freidson 2001; Irvine 1999; Creuss 2000). I henhold til denne kontrakttankegangen gis en profesjon og dermed dens medlemmer skjønnsmyndighet til å forvalte sin spesialkunnskap og tillærte ferdigheter, mens samfunnsmedlemmene til gjengjeld forventer at de handler på en måte som er verdig borgernes tillit. For at denne individuelle skjønnsutøvelsen ikke skal foregå på tillitsreduserende, vilkårlige premisser, sørger profesjonen for sosialisering og kultivering av individuelle ferdigheter på gruppenivå.

\section{Kultivering av skjonn i legerollen på gruppenivå}

Sosialiseringsprosessen som finner sted på gruppenivå innad i den medisinske profesjonen, handler ikke bare om profesjonsmedlemmer som knyttes sammen i et sosialt fellesskap på bakgrunn av felles terminologi, faglige innsikter og erfaringer. Den handler også om profesjonens kollektive selvrefleksjon over eget kunnskaps- og verdigrunnlag og om den vedvarende faglige utviklingen denne refleksjonen impliserer. Denne kollektive aktiviteten pågår i tidsskrifter, på konferanser og $\mathrm{i}$ anledning av andre former for faglige sammenslutninger, og den institusjonaliseres gjennom vedtak i ulike internasjonale og nasjonale legeforeninger. Videre har den medisinske profesjonen selv fagansvaret for utdanningen av sine medlemmer og dermed den faglige kunnskapen og verdiene som setter standardene for legenes virksomhet. For å informere profesjonens medlemmer om forventninger de arbeider under, utarbeides kvalitetsstandarder i form av kliniske retningslinjer og etiske regler. Kvalitetsstandarder muliggjør også at medlemmene kan ansvarliggjøres for sin praksis.

\section{Kultivering av skjønn i legerollen på individnivå}

Den spesifikke medisinske kunnskapen og de spesifikke medisinske ferdighetene omsetter legene i søken etter praktiske løsninger på helseproblemer i møte med pasienter. Alle tiltak som søker å påvirke det epistemiske skjønnet gjennom etiske og faglige standarder, og som er i tråd med det profesjo- 
nen på gruppenivå har anerkjent som et akseptabelt kunnskaps- og verdigrunnlag, representerer ulike former for profesjonens kultivering.

\section{Profesjonsintern strukturering av skjonn i legerollen på individnivå}

For å bevare myndighetenes og befolkningens tillit til at profesjonen ivaretar ansvaret for å yte så god helsehjelp som den kan, er profesjonen gjennom sine institusjoner tvunget til å utføre intern kontroll over sine medlemmer. Muligheten for at medlemmer som ikke opptrer i tråd med profesjonens kvalitetsstandarder, kan bli ekskludert fra profesjonens egne institusjoner, fungerer som en regulerende mekanisme. Dette dreier seg med andre ord om en mekanisme som begrenser den enkeltes frihet til å utøve individuell profesjonell autonomi som er uforenlig med profesjonens kollektivt definerte standarder.

\section{Profesjonelt skjonn i klinisk kontekst}

Den analytiske sammenhengen mellom strukturering og kultivering av skjønn i legerollen i henhold til et samfunns- og et profesjonsperspektiv er nå klargjort.

For å nærme oss en mer nyansert forståelse av det epistemiske skjønnet som er virksomt $\mathrm{i}$ legerollen, tar jeg nå utgangspunkt $\mathrm{i}$ en distinksjon mellom skjønn anvendt ved fastsettelse av helsehjelpsbehov, og skjønn som inngår i den delen av pasientbehandling som har å gjøre med hvordan man behandler andre mennesker generelt. Denne siste varianten dreier seg om den spesifikt relasjonelle dimensjonen ved rollen som pasientbehandler, mens den første kan vi knytte an til de fagtekniske og distributive vurderingene som inngår i klinisk arbeid.

I møte med pasienters behov for helsehjelp fyller legens epistemiske skjønn opp det tomrommet som finnes i fravær av pålagte regler og standarder. Legen må fortolke pasientens behov for helsehjelp slik han eller hun finner det best å gjøre det. Grimen og Molander har vist oss hvordan vi kan nærme oss en analyse av den underliggende strukturen i klinisk skjønnsutøvelse gjennom en utlegning av hvordan skjønn generelt betraktet fungerer som en epistemisk kategori.

\section{En generell modell for epistemisk skjonn}

I kapittelet «Profesjon og skjønn» i boka Profesjonsstudier gjør Grimen og Molander bruk av S.E. Toulmins modell for generell argumentasjon for å få et tak på de generelle kontekstene som trigger epistemisk skjønn (Grimen \& Molander 2008; Toulmin 2003). Deres antagelse er at utøvelse 
av skjønn kan forstås ut fra hvordan praktisk resonnering generelt foregår. Praktisk resonnering involverer data om den konkrete konteksten man er i ferd med å handle i, og handlingsnormer som begrunner konklusjonen om hva man skal gjøre. Toulmin kaller slike handlingsnormer «warrants», mens Grimen og Molander oversetter det til «garantister». Garantister kan være av forskjellige slag, men har til felles at de garanterer overgangen fra premiss til konklusjon. Det kan for eksempel være pliktnormer som peker ut hva man skal gjøre i bestemte situasjoner. Det kan være instrumentelle normer som forteller oss hva vi må gjøre for å oppnå et bestemt mål, og det kan være teleologiske normer som krever av oss at vi streber mot et bestemt mål ved å finne velegnede midler. Samlet utgjør beskrivelser av situasjonen og normene grunner for å handle. Disse grunnene kan selv trenge ytterligere begrunnelse, som dermed vil innebære nye garantister: Garantister som blir brukt for å begrunne en beskrivelse av en kontekst, kalles identifikasjonsregler. Situasjonsbeskrivelsen er da å forstå som en konklusjon basert på visse data i kombinasjon med en identifikasjonsregel som garantist. Normen som begrunner en handling, kan også bli ytterligere rettferdiggjort. Dette skjer dels ved å argumentere for at en norm er valid, det vil si argumentere for at den bør bli anvendt, og dels ved å argumentere for dens anvendbarhet i den aktuelle situasjonen. Mot denne bakgrunnen og under antagelsen om at garantister presenterer seg med varierende grad av styrke langs et kontinuum, konkluderer Grimen og Molander at skjønn er mest virksomt $i$ de situasjoner der garantistene er svakest. Svake garantister er årsakene til uklarhet knyttet til hva situasjonen krever. Skjønn som epistemisk kategori er nødvendig for å bringe situasjonen til en praktisk konklusjon ved «å lukke for ubestemthet», som Grimen og Molander uttrykker det.

\section{Fagteknisk skjønn}

Hvordan kan man beskrive utøvelsen av epistemisk skjønn i en klinisk kontekst? Grimen og Molander gir en nyansert fremstilling av hvordan skjønn tenkes å fungere ved medisinske vurderinger av intervensjoner med et kurativt formål. Behov for helsehjelp kan beskrives på formen tilstandbehandling (Hasman et al. 2006). Den samme relasjonen mellom tilstand og behandling kan også bli lagt ut som et hypotetisk imperativ for medisinsk handling med kurativt formål (Grimen \& Molander 2008). Formålet med kurativ medisin vil være å bedre pasientens helse. For at det skal skje, må man identifisere pasientens tilstand og hva som skal til for å bedre denne. Det hypotetiske imperativet fungerer da som garantist for å bringe dataene om tilstand og behandling til en praktisk konklusjon om hva situasjonen krever av handling: 
Hvis $\mathrm{x}$ (tilstand), så y (behandling). Et eksempel kan være: Hvis blindtarmsbetennelse, så fjerning av blindtarm. Men i en klinisk kontekst kan dette forholdet representere uklarheter på ulike måter som svekker styrken på garantisten (normen), det vil si det hypotetiske imperativet:

1 Det er klart hva x er, men y er uklar (dette beskriver situasjoner der diagnosen er lett å bestemme, men der det ikke finnes noen opplagt standard behandling).

2 Det er uklart hva x er, men y er klar (dette vil være situasjoner der det er vanskelig å stille diagnosen, men behandlingen er konvensjonell).

3 Det er uklart hva både $\mathrm{x}$ og y er (dette er typisk tilfeller der det ikke bare er vanskelig å få tak på akkurat hva det er som forårsaker lidelsen, men også hva som skal til for å fjerne den).

4 Forholdet mellom x og y er uklart i partikulære tilfeller (forbindelsen mellom x og y må empirisk begrunnes, men selv om forbindelsen kan være støttet av aggregert statistikk, er det alltid en mulighet for at y ikke er løsningen til x i konkrete tilfeller).

Samtlige situasjoner som er systematisk beskrevet her, involverer epistemisk usikkerhet i tilknytning til én eller flere av garantistens strukturelle elementer. Garantisten har med andre ord liten grad av styrke. Situasjonene påkaller dermed bruk av skjønn for å lukke for ubestemtheter ved disse usikkerhetsmomentene og gjøre det mulig å nå en praktisk konklusjon om hva situasjonen krever av intervensjon.

Vi kan gå utover Grimen og Molanders fremstilling og argumentere for at en tilsvarende garantistmodell også kan gjelde innen palliativ medisin. Formålet med behandlingen innen palliativ medisin er ikke å gjenopprette helse, noe som derimot er formålet i kurativ medisin, men å sikre smertelindring. Garantisten har samme instrumentelle karakter, der formålet er kjent (oppnå smertelindring), og der $\mathrm{x}$ (opphavet til smertene/tilstand) og $\mathrm{y}$ (behandling) kan fremstilles som et hypotetisk imperativ med de samme potensielle usikkerhetsmomenter som presenteres i punktene 1-4 ovenfor.

Når det gjelder forebyggende (preventiv) medisin, kan man også argumentere for at garantisten har den samme logiske strukturen. Formålet med preventiv behandling er aktivt å tilrettelegge for god helse generelt og å imøtekomme forutsette helseproblemer på et tidlig stadium. I begge tilfeller, både der forebygging igangsettes uavhengig av identifiserte tilstander, og der forebygging gjelder en identifisert tilstand som assosieres med et potensielt, forventet resultat ved fravær av preventive intervensjoner, gjelder det hypotetiske imperativet: Hvis $\mathrm{x}$, så $\mathrm{y}$, som fremstilt over. Forskjellen mellom preventiv behandling og kurativ og palliativ behandling er i hovedsak knyttet til den potensielle styrken på garantisten. I preventiv medisin handler 
man på basis av minst ett ekstra usikkerhetsmoment i tillegg til 1-4 over. Dette kan beskrives som:

5 Det er uklart om en identifisert tilstand $\mathrm{x}$ vil utvikle seg i den retningen som begrunner (den preventive) behandling $\mathrm{y}$.

Skjønnsmessig aktivitet som lukker for ubestemtheter i kliniske kontekster i henhold til punktene 1-5, opererer under formålene om å kurere, lindre eller forebygge og er basert på teoretisk eller erfaringsbasert kunnskap om symptomer, årsakssammenhenger, tilgjengelige virkemidler og effekter. Datagrunnlaget som potensielt inngår i virksom klinisk behandling, favner bredt og inkluderer i tillegg til biologiske data også ikke-biologiske forhold som har betydning for individuelle pasienters evne til å nyttiggjøre seg av behandlingen. Normene som ligger til grunn for skjønnsutøvelse i klinisk arbeid, må primært forstås instrumentalistisk i henhold til målsetningene om å forebygge, kurere og lindre. Nødvendigheten av å realisere disse instrumentalistiske normene kan i neste omgang begrunnes på bakgrunn av en pliktnorm om å yte hjelp, men den essensielle normative strukturen ved denne formen for klinisk arbeid er instrumentlistisk (Lian \& Skolbekken 2003). Vi kan referere til denne skjønnsbruken som utøvelse av et fagteknisk skjønn.

\section{Data og normer som grunnlag for fagteknisk skjonnsanvendelse}

Identifikasjonsregler som ligger til grunn for identifisering av relevante fagtekniske forhold, vil kunne understøttes av både vitenskapelig etablert og erfaringsbasert kunnskap. Det samme gjelder normene som understøtter relasjonen mellom $\mathrm{x}$ (tilstand) og $\mathrm{y}$ (behandling). I så måte vil både evidensbasert medisin, ulike varianter av kollektivt etablerte fagstandarder (for eksempel behandlingsprotokoller) og individuelle erfaringer kunne danne grunnlaget for fagtekniske slutninger om x og y i klinisk kontekst.

\section{Distributivt skjonn}

I forlengelsen av oversikten over uklarheter involvert i fagteknisk skjønnsanvendelse, kan vi nå videreutvikle perspektivet og klargjøre også andre integrerte ubestemtheter involvert i klinisk praksis. Dette er ubestemtheter som profesjonell skjønnsutøvelse må bidra til å lukke.

Vi kan utvide listen til Grimen og Molander med enda en ny kategori. Denne kategorien vil innbefatte situasjoner der både x og y er klar, men der forbindelsen mellom x og y er uklar med hensyn til normativ status. Selv om 
y imøtekommer x empirisk, er det ikke gitt at koblingen mellom $\mathrm{x}$ og y representerer et normativt definert behov som tilsier at y bør tilbys:

6 Det er klart hva både x og y er (stor nese-plastisk kirurgi), og forholdet mellom $\mathrm{x}$ og y er empirisk ukontroversielt, men det er normativt uklart om hvis $\mathrm{x}$, så $\mathrm{y}$.

Med dette scenarioet på listen kan vi tydeliggjøre at skjønn også kan være påkrevd for å vurdere om en erkjent kobling mellom tilstand og behandling faktisk representerer et normativt rettferdiggjort behov for helsehjelp i en gitt situasjon selv om både tilstand og effektiv behandling er kartlagt. Er et uskyldig utslett noe man kan unnlate å behandle medisinsk selv om veldokumenterte metoder er tilgjengelige? Har kreftpasienten et behov for en svært kostbar behandling som kan gi ham eller henne to måneder lenger å leve?

Går vi tilbake til Grimen og Molanders presentasjon av Toulmins modell for epistemisk skjønn, så ser vi at i disse eksemplene trenger vi en ytterligere begrunnelse (utover en instrumentell rettferdiggjøring) for å ende opp med en praktisk konklusjon om at koblingen mellom en gitt tilstand og en gitt behandling representerer et helsehjelpsbehov man skal imøtekomme. Med andre ord kommer her behovet for å anvende skjønn inn på en ny måte. Det lukker ikke for ubestemthet knyttet til tilstanden og/ eller behandlingen, eller for forholdet disse imellom. Det retter seg med andre ord ikke primært mot de fagtekniske elementene i koblingen mellom tilstand $\mathrm{x}$ og behandling $\mathrm{y}$. Derimot kan det bidra til å lukke for ubestemthet knyttet til det åpne spørsmålet om hvem som skal få hva og når innenfor en helsetjeneste.

Skjønnsutøvelsen som er beskrevet i punkt 6 kan utøves med henblikk på koblingene 1-5, men da først etter at det fagtekniske skjønnet som primært er rettet mot de fagtekniske betingelsene for helsehjelp, har lukket for ubestemthet knyttet til tilstand $\mathrm{x}$ og/eller behandling $\mathrm{y}$, eller forbindelsen mellom disse. Dette andre skjønnet lukker deretter for ubestemthet med hensyn til hvorvidt en gitt kobling mellom x og y representerer en tjeneste det er relevant å tilby i en bestemt kontekst. Analytisk må vi skille denne andre skjønnsbruken fra den fagtekniske, og vi kan derfor kalle denne bruken av skjønn utøvelse av distributivt skjønn.

I henhold til denne analytiske fremstillingen av forhold som trigger skjønnsutøvelse i en klinisk kontekst, gir det nå mening å identifisere en avstand mellom den skjønnsmessige lukkingen av ubestemtheter knyttet til fagtekniske faktorer som tilstand, behandling og forholdet disse imellom, og selve den praktiske konklusjonen om å igangsette behandling. Dette epistemiske gapet rommer potensielt distributivt skjønn. I det følgende gis 
eksempler på hvordan denne dimensjonen ved skjønnsanvendelse også er virksom i diagnostisk og forebyggende klinisk arbeid.

I forebyggende klinisk arbeid kan man også stille spørsmål ved hvorvidt koblinger mellom $\mathrm{x}$ og y der $\mathrm{x}$ og y og forholdet disse imellom er avklart, virkelig representerer et behov for helsehjelp. Formålet med forebyggende medisin er å fremme helse og identifisere risikofaktorer og behandling som kan redusere risikoen for å utvikle sykdomstilstander. Allikevel kan man alltids stille spørsmålet om det er riktig å utsette pasienter for potensielt belastende forebyggende behandling for nærmere spesifiserte, trivielle eller lite belastende sykdommer? Og om det er riktig ressursbruk å behandle forebyggende ved lav risiko for at en tilstand utvikler seg i uønsket retning?

I diagnostisk klinisk arbeid som innebærer at $\mathrm{x}$ er uklar, er skjønnet virksomt når det gjelder å avslutte ubestemthet knyttet til tilstand $\mathrm{x}$. For å avdekke x er skjønn aktivt når det gjelder å stille de riktige spørsmålene gjennom undersøkelsen. I diagnostisk arbeid vil normativt skjønn også kunne opptre forut for at det fagtekniske skjønnet har avsluttet ubestemthet knyttet til x. Dette aspektet ved skjønn relateres da til valgene man tar med hensyn til tester og spesialisthenvisninger for å kunne komme frem til en konklusjon om hva som feiler pasienten. I valg av metodisk fremgangsmåte dukker distributivt skjønn opp (som en teoretisk mulighet) knyttet til bruk av tjenester for å fullføre det diagnostiske arbeidet. Er dette et medisinsk problem det er verdt å bruke mye ressurser på å få kartlagt? Praktiske konklusjoner om diagnostiserende tiltak basert på denne typen vurderinger kan fylle gapet mellom en observert tilstand og en igangsatt eller avvist utredning.

Vi har nå sett at det er et integrert forhold mellom fagtekniske og distributive skjønnsvurderinger som sammen leder til konklusjoner om helsehjelpsbehov. Dette betyr at klinisk skjønn ikke utelukkende bør forstås som alene basert på fagtekniske vurderinger. Følgelig bør heller ikke klinisk skjønn beskrives som en verdinøytral faglig fundert epistemisk aktivitet. Dette kan tilsløre normative problemstillinger involvert i vurderinger av helsebehov, og dermed utruste legene med større normativ autoritativ makt enn den er mulig for andre å ansvarliggjøre dem for.

\section{Data og normer som grunnlag for distributivt skjonn}

Normative vurderinger kan potensielt fylle ut gapet mellom fagtekniske, lukkede skjønnsvurderinger og igangsatt behandling i kurativ, forebyggende og diagnostiserende medisin. Disse vurderingene kan oppsummeres i spørsmålet: Bør denne personen ha denne helsetjenesten nå? Det må presiseres at dette er vurderinger som potensielt finner sted. Poenget her er at selv om et distributivt skjønn ikke eksplisitt utøves gjennom en ekstra konklusjon i tillegg til de fagtekniske vurderingene, så innebærer et tilbud om 
en bestemt helsetjeneste at legen gir sin tilslutning til at denne pasienten bør ha denne behandlingen nå. Legen signaliserer dermed at helsehjelpen er relevant å yte ut fra rammene for helsetjenesten. Det teoretiske gapet jeg her peker på, rommer kort og godt klinikernes mulige overveielser over hva som fagteknisk kan tilbys, og hva som bør tilbys i en konkret kontekst. Denne konkrete konteksten omfatter den individuelle pasientens medisinske historie og generelle livsbetingelser samt de eksterne rammene for helsehjelpen, nemlig helsetjenestesystemet som behovsvurderinger finner sted innenfor. Konteksten rommer de fagtekniske vurderingene, men bringer samtidig med seg et bredere datagrunnlag som potensielt kan begrunne legenes handling.

Ulike begrunnelser som nytte- og kostnadsvurderinger og individuelle karakteristikker kan fylle gapet mellom fagtekniske, skjønnsbaserte slutninger og den praktiske konklusjonen om å tilby en behandling. For at dette skal være hensyn som fremtrer som relevante data i en kontekstbeskrivelse, er det en forutsetning (i henhold til Grimen og Molanders utlegning av Toulmin) at det finnes normer som begrunner at dette er forhold som har betydning. Generelt sett vil dette dreie seg om normer knyttet til en avklaring av selve det normative formålet med helsehjelpen (for eksempel «god» helsehjelp, «rettferdig» helsehjelp) og vurderinger som kreves for å realisere dette målet. Hvis målet for eksempel er at helsehjelpen skal være rettferdig, så kan substansielle normer spesifisere hvilke karakteristikker ved en tilstand og/eller behandling som må vektlegges. Dette kan dreie seg om fagtekniske vurderinger som tilstandens alvorlighetsgrad, behandlingstiltakets forventede effekt, sosioøkonomiske faktorer som forhindrer pasienten i å nyttiggjøre seg behandlingen, og behandlingens kostnadseffektivitet. Disse substansielle normene vil igjen kunne begrunnes i generelle prinsipper om distributiv rettferdighet.

\section{Relasjonelt skjonn}

Profesjonell skjønnsutøvelse i en klinisk kontekst involverer pasienter, pårørende og kolleger. Skjønn vil dermed også være påkrevd for å lukke for ubestemtheter knyttet til omsetting av sosiale, etisk funderte normer i all konkret mellommenneskelig interaksjon. Helt generelt kan vi si at skjønnsutøvelse i mellommenneskelige relasjoner bør være betinget av at involverte parter behandler hverandre som moralsk likeverdige. Ideen om moralsk likeverd kan betraktes som en ukontroversiell regulativ idé som gjenfinnes i moderne, etisk teori, politisk rettighetstenkning og som grunnlag for vestlig liberal og demokratisk statsdannelse (Gosepath 2005). Vi anerkjenner hverandre som moralsk likeverdige når vi tolererer og aksepterer ulike oppfatninger og ønsker, og når vi søker å unngå undertrykkelse i form av 
utnytting, misbruk og diskriminering. Skjønn er påkrevet for å «avslutte ubestemtheter» knyttet til hvordan man skal handle for å realisere den andres likeverd i konkrete kliniske kontekster. Denne dimensjonen ved profesjonell skjønnsutøvelse må holdes adskilt fra skjønnsutøvelse ved fastsettelse av helsehjelpsbehov (fagteknisk og distributivt), og vi kan betegne den «relasjonelt skjønn».

Hvordan den enkelte lege utøver et relasjonelt skjønn, viser seg i hvordan han eller hun omsetter den generelle moralske normen om å behandle andre som moralsk likeverdige - til tross for asymmetriske maktforhold som følger av strukturelt betinget skjønnsmyndighet - i sin konkrete omgang med pasienter, pårørende og kolleger. Mer nyansert fremstilt kan uklarheter som påkaller relasjonell skjønnsutøvelse, også presenteres som et hypotetisk imperativ: Hvis x', så y' (x' er situasjonsbeskrivelse, y' er handling). Men i dette alternative skjemaet er det overordnede formålet å realisere moralsk likeverd. I tillegg til tilsvarende strukturelle uklarheter som presenteres i punktene 1-4 i oversikten over fagteknisk og distributivt skjønn (i det herværende skjemaet: 1'-4'), vil det her også være uklarhet knyttet til fortolkningen av det overordnede formålet. Hva betyr det «å realisere moralsk likeverd»? Vi får dermed:

5') Det er uklart hva formålet «å realisere moralsk likeverd» betyr.

Videre vil det relasjonelle skjønnet påkalles på et nytt nivå for å avslutte ubestemtheter knyttet til det å finne løsninger på konflikter mellom skjønnsbaserte konklusjoner av fagteknisk og distributiv art på den ene siden (konklusjoner om hvilken spesifikk behandling pasienten bør ha), og eksterne barrierer som hindrer legen fra å tilby denne behandlingen på den andre. Dette kan være barrierer av normativ, pragmatisk og personlig karakter (Bærøe \& Norheim 2010). Hva man skal gjøre når ulike former for barrierer står i veien for tiltak man skjønnsmessig har vurdert at pasienten $b ø r$ tilbys, vil være et åpent spørsmål som i konkrete tilfeller påkaller skjønn for å lukke de ubestemtheter som dermed oppstår. Denne skjønnsutøvelsen kan betraktes som en form for relasjonelt skjønn med et overordnet formål om å realisere moralsk likeverd. Å likegyldig tilpasse behandlingen til barrierene (som i prinsippet kan unngås) ved å tilby et behandlingsalternativ som ikke sammenfaller med det man erkjenner pasienten $b ø r$ ha, bidrar ikke til å realisere moralsk likeverd. Uklarheter i forbindelse med hvordan man skal håndtere ulike former for barrierer som hindrer at pasienten får den hjelpen vedkommende bør ha, kan inngå som nok et punkt i oversikten over forhold som trigger relasjonelt skjønn:

6') Det er uklart hvordan man skal håndtere barrierer som forhindrer en $\mathrm{i}$ å tilby pasienten behandling man erkjenner vedkommende $b ø r$ ha. 


\section{Data og normer som grunnlag for relasjonelt skjonn}

Datagrunnlaget som påkaller relasjonelt skjønn i klinisk kontekst vil være forhold som truer ivaretagelse av moralsk likeverd. Identifikasjonsregler knyttet til erkjennelse av relevante situasjonskarakteristikker, kan relateres til erfaringsbasert, sosialisert «dagliglivskunnskap» eller teoretisk funderte, normative, moralfilosofiske teorier om rett og galt. Tilsvarende kan den samme erfaringskunnskapen og de samme moralske normene støtte opp under vurderingene av hva det vil innebære å omsette formålet om å realisere moralsk likeverd gjennom handling i konkrete situasjoner.

\section{Avgrensning og kultivering av skjonn i klinisk kontekst}

Når vi nå har skilt mellom ulike dimensjoner ved legers profesjonelle skjønn, kan vi bedre systematisere hvordan styringssystemer kan avgrense legers skjønnsmessige virke på den ene siden, og hvordan profesjonen kan besørge kultivering av skjønnsmessige avgjørelser på den andre. På bakgrunn av data og normgrunnlaget for de ulike skjønnsdimensjonene og de ulike styrkegradene disse garantistene logisk sett gir rom for, kan vi diskutere ulike strategier som vil kreves for å styrke adekvat skjønnsutøvelse i henhold til de ulike dimensjonene. Dette vil gjøre oss i stand til å besvare spørsmålet om hvilke forordninger som må være på plass for at resten av samfunnet skal ha en berettiget tillit til legers skjønnsbruk.

\section{Avgrensning og kultivering av fagteknisk skjonn}

Den medisinske profesjonens omsetting av fagteknisk kunnskap i klinisk kontekst er i liten grad regulert av eksternt pålagte standarder selv om lovverket etablerer de ytre rammene for anvendelse av denne kunnskapen. Vi kan se på noen eksempler i en norsk kontekst. Lov om alternativ behandling avgrenser autorisert helsepersonells enemerker ved å forby andre enn autorisert helsepersonell å utføre medisinske inngrep eller behandling som kan medføre alvorlig helserisiko, behandling av allmennfarlige smittsomme sykdommer og alvorlige sykdommer og lidelse (Helse- og omsorgsdepartementet 2003). Samtidig pålegger lov om helsepersonell leger ansvaret for de medisinske beslutningene når legene samarbeider med annet helsepersonell, men også at de på linje med annet helsepersonell skal innrette seg etter sine faglige kvalifikasjoner og innhente bistand eller henvise pasienten videre om nødvendig og mulig (Helse- og omsorgsdepartementet 1999b). Videre tydeliggjør lov om pasientrettigheter helsepersonells korresponderende forpliktelser når den beskriver pasientenes rettmessige krav overfor helsetjenesten (Helse- og omsorgsdepartementet 1999a). Legene er også pålagt å føre journal for pasientene (Helse- og omsorgsdepartementet 
1999b). Betraktet som en strategi for å akkumulere og videreføre kunnskap om individuelle pasienter er dette en inngripen som reduserer skjønnsutøvelse med hensyn til valg av faglig arbeidsmetode. Legene forventes også å følge nasjonale behandlingsretningslinjer. Samlet avgrenser reguleringer som dette legenes rom for fagteknisk skjønnsutøvelse.

Kultivering av god fagteknisk skjønnsutøvelse er et hovedanliggende for profesjonens institusjonaliserte utdanningsforløp og er også helt sentral i den medisinske fagtidsskriftkulturen. Kliniske retningslinjer kan redusere usikkerhetsmomenter som ellers ville ha påkalt skjønn. Selv om forskning i så måte styrker garantister, består fremdeles utfordringen med å identifisere $\mathrm{x}$ i partikulære kontekster og å vurdere om retningslinjenormen på formen «hvis $\mathrm{x}$, så $\mathrm{y»} \mathrm{er} \mathrm{appliserbar} \mathrm{i} \mathrm{den} \mathrm{gitte} \mathrm{casen} \mathrm{(punkt} \mathrm{4).} \mathrm{Et} \mathrm{komplekst,} \mathrm{sam-}$ mensatt sykdomsbilde kan være grunner til ikke å følge opp det hypotetiske imperativet i retningslinjene (Tanenbaum 1993). Det samme gjelder ikkebiologiske forhold som forhindrer pasienten fra å nyttiggjøre seg av den standardiserte behandlingen (Bærøe \& Bringedal 2011). En rest av skjønn vil alltid måtte påkalles for å lukke for ubestemthet knyttet til hvorvidt den partikulære casen faktisk faller inn under den generelle kunnskapsbaserte sammenhengen som presenteres i retningslinjer. Denne biten av det fagtekniske skjønnet unndrar seg målrettet kultivering og vil i stor grad måtte være prisgitt erfaring og individuelle strategier for akkumulering av egen erfaringskunnskap (som refleksjon og diskusjon med kolleger).

\section{Avgrensning og kultivering av distributivt skjonn}

I norsk kontekst er legers distributive skjønn strukturelt avgrenset gjennom lov om helsepersonell, som krever at «helsehjelpen ikke påfører pasienten, helseinstitusjonen, trygden eller andre unødvendig tidstap eller utgift» (Helse- og omsorgsdepartementet 1999b). Videre er helsehjelpen i Norge et offentlig tilbud finansiert av den norske staten. Dette innebærer at profesjonens bidrag i fordeling av offentlig helsehjelp må sees innskrevet i en generell byråkratisk struktur for fordeling av sosiale goder. Legene er dermed underlagt det formelle rettferdighetskravet om likebehandling og samfunnets substansielle fortolkninger om hva rettferdig fordeling innebærer.

Ulike ordninger som prioriteringsforskriften, prioriteringsveiledere, blåreseptordninger, nasjonale behandlingsretningslinjer samt politiske avgjørelser om ressursallokeringer på pasientgruppenivå avgrenser profesjonens skjønnsmyndighet over rettferdige fordelingsspørsmål. Utover dette er normer som begrunner distribusjon av helsehjelp innen den offentlige helsetjenesten, i liten grad artikulert i substansielle regler eller prinsipper som avgrenser legenes distributive skjønn. Klinikere, og da spesielt all- 
mennpraktikere, står temmelig fritt i å vurdere det normative grunnlaget for helsehjelpsbehov.

I henhold til samfunnskontrakten foreligger det en forventning om at legene anvender det distributive skjønnet til beste for samfunnet. I sine etiske regler synliggjør profesjonen at den er dette ansvaret bevisst:

$\$ 12$. En lege skal i sin virksomhet ta tilbørlig hensyn til samfunnets økonomi. Unødige eller overflødig kostbare metoder må ikke anvendes [...]. Legen må bidra til at medisinske ressurser fordeles i henhold til allmenne etiske normer. En lege må ikke på noen måte søke å skaffe enkeltpasienter eller grupper en uberettiget økonomisk, prioriteringsmessig eller annen fordel. (Den Norske Legeforening 1961, 2002)

Disse reglene skal bidra til å lukke for ubestemtheter knyttet til behandlingen man skal tilby.

Men hva innebærer «allmenne etiske normer» i ressursfordelingsspørsmål? Selv om det kan være allmenn enighet om generelle kriterier for fordeling (som for eksempel prioriteringsprinsippene i Lønning-utvalgene), så er det mindre grunn til å anta at det vil være allmenn enighet om fortolkning av prinsippene ved anvendelse på konkrete tilfeller, og spesielt ikke i tilfeller der ulike prinsipper må veies mot hverandre. Med sitt begrep om «the burdens of judgment» forklarer John Rawls oss hvorfor vi i prinsippet må forvente uenighet om verdispørsmål (Rawls 1993). En av faktorene som forklarer dette, er ulike erfaringer vi gjør oss gjennom livet. Erfaringene bidrar til å forme våre verdioppfatninger. En tilstrekkelig ulik erfaringsbakgrunn kan forklare at skjønn utøves og oppfatninger formes på bakgrunn av ulike verdier. Som en konsekvens av dette (og fem andre faktorer Rawls nevner) vil vi måtte forvente en viss vilkårlighet når det gjelder de «egendefinerte» handlingsnormene som individuelle klinikere legger til grunn for distributiv skjønnsutøvelse.

En spørreundersøkelse utført blant et representativt utvalg norske leger, indikerer også at legene er delte i sitt syn på sentrale fordelingsspørsmål. Tilnærmet halvparten av respondentene var helt eller delvis enig i følgende påstand, mens den andre halvdelen var helt eller delvis uenig: «Leger bør bidra til å utjevne helseforskjeller i befolkningen ved å yte ekstra hjelp til pasienter med lav sosioøkonomisk status» (Bringedal \& Bærøe 2010). Det er med andre ord god grunn til å sette spørsmålstegn ved om det eksisterer «allmenne etiske normer», og følgelig også om legene er enige om hva som utgjør en «uberettiget» fordel ved fordeling av helsehjelp.

Hvis vi ikke kan forvente at det eksisterer allmenne etiske normer som former legenes distributive skjønnsutøvelse, står vi overfor flere problemer. For det første undergraver legenes vilkårlige fundament for skjønnsmessige distributive vurderinger muligheten for at befolkningen blir sikret likebehandling gjennom den organiserte helsetjenesten. Uten reguleringer som lukker for skjønnsutfoldelse med hensyn til vurderinger av nytte, kostnad 
og individspesifikke kriterier, må vi forvente ulike distributive vurderinger blant legene av like kasus. For det andre blir legene sittende med avgjørelser som i sin essens er politiske. Dette dreier seg om rettferdig forfordeling av helsehjelp, men uten at disse beslutningene er regulert gjennom demokratiske lovgivende prosesser. Dette siste problemet har blant andre E.O. Eriksen påpekt i forbindelse med skjønnsbasert distribusjon av velferdsgoder på bakkenivå. Han betegner denne manglende politiske kontrollen over siste ledd i fordelingssystemet som «demokratiets sorte hull» (Eriksen 2001). Spørsmålet blir dermed om det er ønskelig å avgrense legenes distributive skjønnsutfoldelse ytterligere gjennom et eksternt regulerende regelverk, eller om det kan tilrettelegges for bedre kultivering innad i profesjonen for å sikre at like tilfeller blir behandlet likt.

Det er gode grunner til å unngå ekstern avgrensning av legers distributive skjønn gjennom spesifiserte regler for hvem som skal få hva og når. For det første har vi allerede sett at det distributive skjønnet er tett integrert med det fagtekniske skjønnet. Videre har vi sett at anvendelse av fagtekniske retningslinjer alltid hviler på en svak garantist med hensyn til om partikulære tilfeller faktisk faller inn under de kunnskapsbaserte, generelle sammenhengene retningslinjene forutsetter. Dette er grunnen til at kliniske retningslinjer har form som nettopp «retningslinjer», og ikke «regler». Det distributive skjønnet vil følge med «på lasset» når det fagtekniske skjønnet tilsier at pasientens behov for helsehjelp ikke er forenlig med imperativet i den kliniske retningslinjen. Å skulle innskrenke legenes skjønnsvurderinger gjennom fastsatte regler om hvem som skal få hva når for å sikre likebehandling, vil dermed undergrave den enkelte pasients rett til fagteknisk, individuelt tilrettelagt behandling. Et krav om regelbasert distributiv likebehandling vil følgelig overstyre de fagtekniske vurderingene med risiko for å tilby mindre adekvat, tilpasset individuell behandling. Dette blir problematisk i henhold til en målsetning om å fremme likhet i helse. Uten lempelig tilpasning av helsehjelp når det gjelder for eksempel den enkeltes evne til å nyttiggjøre seg av et fagteknisk, standardisert behandlingsopplegg, blir individuell behandling urettferdig (Bærøe \& Bringedal 2011). Så forsøk på å avgrense legers distributive skjønnsmyndighet gjennom spesifiserte behandlingsregler (og ikke «retningslinjer») presser frem en spenning mellom rettferdig individuell behandling versus rettferdig likebehandling.

Det virker rimelig og ukontroversielt å først og fremst vektlegge adekvat fagteknisk, individuell behandling til tross for at denne strategien kan gå på bekostning av likebehandlingsprinsippet. Men dette valget utelukker jo ikke at likebehandlingsprinsippet kan søkes ivaretatt gjennom profesjonens kollektive kultiveringsstrategier. Profesjonen kan selv institusjonalisere ordninger som fokuserer på det distributive skjønnet, og som streber mot en likere praksis basert på 1) tilrettelegging for offentlig dialog og kollektiv utprøving av begrunnelser for ulike distributive normer, og 2) individuelle 
avklaringer av eget normgrunnlag for skjønnsbaserte fordelingsbeslutninger (Bærøe 2009). Slike tiltak gir oss ikke grunn til å tro at alle leger dermed vil reflektere seg frem til det samme distributive normgrunnlaget, og på denne måten også vil sikre likebehandling. Men ved å åpne opp for diskusjon med samfunnsmedlemmer for øvrig, tilrettelegger profesjonen for at i det minste dårlig begrunnede fordelingsnormer vil kunne forkastes. I så måte kan man forvente en viss reduksjon i vilkårlighet, det vil si i et svært forskjelligartet normgrunnlag. I tillegg synliggjør profesjonen på denne måten at den erkjenner sitt ansvar for beslutninger som ikke bare er medisinske, men også politiske i sin karakter. Ved å tilrettelegge for ekstern kritikk og tillemping av det politiske beslutningsgrunnlaget for legers avgjørelser blir også befolkningens tillit til at profesjonen håndterer sitt ansvar til samfunnets beste, rettferdiggjort. Denne typen kultiveringstiltak fremstår dermed som viktig både fra et epistemisk, et rettferdighets- og et tillitsperspektiv.

Ett poeng å merke seg her er at i en adekvat kultivering av det distributive skjønn er ikke profesjonen - og kan heller aldri bli - en selvtilstrekkelig premissleverandør. Her skiller kultiveringen av det distributive skjønnet seg $i$ en vesentlig forstand fra kultiveringen av det fagtekniske skjønnet. Til tross for bistand fra andre akademiske disipliner i kunnskapsutviklingen ekskluderer kultivering av fagtekniske ferdigheter profesjonseksterne oppfatninger om riktige og gale fagtekniske beslutninger.

\section{Avgrensning og kultivering av relasjonelt skjonn}

Både profesjonsinterne og -eksterne regelsystemer bidrar til å redusere den individuelle utøverens rom for valg av egendefinerte normative standarder i fortolkningen av hva det innebærer å behandle andre som moralsk likeverdige. Lovgivning som beskytter pasienters autonomi gjennom eksplisitte forbud og plikter for helsepersonell, og etablerte pasientrettigheter som krav om samtykke griper rett inn i den relasjonelle dimensjonen ved profesjonelt skjønn og reduserer legens skjønnsmyndighet til å overprøve pasientens autoritative kunnskap om sitt eget beste (Helse- og omsorgsdepartementet 1999a).

Samtidig kan profesjonen selv gjennom sin etiske kodeks bidra til å kultivere den relasjonelle skjønnsutøvelsen. Både internasjonale og nasjonale etiske regler for leger spesifiserer nærmere hva det innebærer å behandle pasienten respektfullt som en moralsk likeverdig (Den Norske Legeforening 1961, 2002; World Medical Association 2006). Etiske regler lukker for ubestemtheter for hva som er relevante forhold å være oppmerksom på, og angir generelle handlingsregler for hva som skal til for å realisere moralsk likeverd i kliniske kontekster. På et generelt nivå kan etiske regler fungere som kultiverende, bevisstgjørende standarder for utøvelse av relasjonelt 
skjønn, mens selve fortolkningsarbeidet som kreves ved omsetting av reglene i komplekse, konkrete kontekster, påkaller uunngålig også her skjønn for å lukke for situasjonsrelaterte ubestemtheter. Dermed vil det være påkrevd med en annen form for kultivering enn det etiske regler alene kan besørge.

Kultivering av profesjonsmedlemmenes evne til adekvat å omsette etiske regler i praksis kan styrkes gjennom ulike tiltak. Institusjonaliserte gruppediskusjoner vil være et lavterskeltilbud der man i kollegialt felleskap kan få hjelp til å klargjøre erfarte etiske dilemmaer, og motta innspill til håndtering. Ved mer sammensatte og vanskelige problemstillinger kan kliniske etikk-komiteer eller lignende utvalg med spesialkompetanse i etikk fungere som rådgivende instanser. Her kan det imidlertid være en utfordring at det i den medisinske kulturen ligger en holdning om å unngå innblanding fra utenforstående i medisinetiske skjønnsspørsmål (Pedersen et al. 2009). Dersom den påkrevde spesialkompetansen i etikk antas å sammenfalle med ekstern, fagteoretisk etikk-kunnskap, er det grunn til å anse profesjonens motstand mot innblanding som berettiget. Helsehjelpens spesifikke premisser inkluderer blant annet møter med lidelse og død som bidrar til helsehjelpsarbeidets særegne etiske dimensjon. Dette gir gode argumenter for at medisinsk etikkundervisning må løsrive seg fra en teknisk, vitenskapelig fremstillingsform, og snarere integreres gjennom et erfaringsbasert undervisningsopplegg (Cowley 2005). Tilsvarende virker det rimelig å forvente at klargjøring og håndtering av medisin-etiske konflikter i konkrete situasjoner som involverer helsearbeidere, pasienter og pårørende, finner en form og et språk som gjør det mulig å diskutere problemstillingen tett opp til den erfaringsbaserte etikkforståelsen ikke-fagetikere besitter. Den spesialkompetansen i etikk som kliniske etikk-komiteer først og fremst trenger, handler derfor om å kunne innta rollen som «fasilitator» av diskusjonsprosessen på disse premissene snarere enn å skulle dosere etisk teori. Metodisk sett bør dermed kanskje rollen som «fasilitator» ideelt sett bekles av helseutdannede med tilleggskompetanse i etikk.

Like fullt vil det fra et epistemologisk perspektiv også være ønskelig med representanter i utvalget uten spesifikk helsepersonellerfaring. Profesjonseksterne medlemmer kan bringe nyttige perspektiver som hjelper helsehjelpsarbeidere til å se seg selv, sine oppfatninger og sin egen rolle utenfra. Fagetikere med trening i konsistent perspektivering og analyse kan fungere som verdifulle støttespillere i en slik prosess. I dette perspektivet vil bredt sammensatte kliniske etikk-komiteer eller utvalg ha en viktig funksjon i kultiveringen av helsepersonells evne til å omsette etiske retningslinjer i komplekse, konkrete situasjoner.

Adekvat kultivering av legers relasjonelle skjønn vil i tillegg forutsette profesjonseksterne innspill i også ett annet viktig henseende. Den asymmetriske maktrelasjonen som konstituerer et forhold mellom lege og pasient/ 
pårørende, krever kunnskapsformidling om hvordan moralsk likeverd forsterkes og undergraves i denne typen relasjoner. I denne sammenheng er det pasienter og pårørende som besitter den «eksklusive erfaringskunnskapen» om hva som fremmer eller truer moralsk likeverd. Profesjonens kultivering av et adekvat relasjonelt skjønn ser dermed ut til å være betinget av at denne formen for profesjonseksterne erfaringer innhentes og bringes inn $i$ utdanningen av profesjonsmedlemmene. Ved hjelp av samfunnsfaglig kvalitativ metode kan situasjoner der pasienter og pårørende opplever å bli møtt med moralsk anerkjennelse, og vel så viktig, situasjoner der de har følt mangel på respekt og anerkjennelse, kartlegges, systematiseres og presenteres. Hensikten med dette vil være å bevisstgjøre profesjonsmedlemmene om de relasjonelle strukturene de forventes å fremme. N. Jacobsons arbeider om «verdighet» $\mathrm{i}$ helsehjelpskontekster kan tjene som eksempel på hvordan dette kan gjøres (Jacobson 2009b; Jacobson 2009a). Når det gjelder adekvat utøvelse av relasjonelt skjønn, kan og bør altså profesjonens skjønnsmessige kultiveringsstrategier også basere seg på utenforstående premissleverandører for å oppfylle kravet i samfunnskontrakten om å handle til samfunnets beste.

\section{Konklusjon}

Denne gjennomgangen av skjønn i legerollen har vist hvordan skjønn kan forstås i henhold til et strukturerende og avgrensende samfunnsperspektiv på den ene siden, og et kultiverende profesjonsperspektiv på den andre siden. Videre har en analyse av legeskjønnet i henhold til en distinkt fagteknisk, en distributiv og en relasjonell dimensjon muliggjort en nyansert og systematisk diskusjon av hvordan profesjonen selv kan tilrettelegge for en kvalitetsfremmende kultivering av medlemmenes skjønnsutøvelse. En vesentlig klargjøring følger fra denne diskusjonen: Den medisinske profesjonen kan ikke og bør ikke betraktes som en selvtilstrekkelig premissleverandør når det gjelder å sikre adekvat kultivering av medlemmenes skjønnsutøvelse i en klinisk kontekst. I denne artikkelen har jeg vist hvordan dette først og fremst gjelder ved distributiv og relasjonell skjønnsutøvelse, og jeg har spesifisert profesjonseksterne bidrag til kultiveringen. Ved å sørge for at velegnede kultiveringsstrategier rettes mot disse skjønnsdimensjonene og institusjonaliseres i profesjonens pågående selvregulering, kan befolkningens berettigete tillit til profesjonen styrkes ytterligere. 


\section{Litteratur}

Bringedal, B. \& Bærøe, K. (2010) Bør leger bidra til å utjevne sosial ulikhet i helse? Tidsskrift for den Norske Legeforening 2010, 130, s. 1024-1027.

Bærøe, K. \& Norheim, O.F. (2010) Etikk i legevaktarbeid. Et studiehefte fra Nasjonalt kompetansesenter for legevaktmedisin. Rapport nr. 6-2010. Bergen: Nasjonalt kompetansesenter for Legevaktmedisin, Uni helse.

Bærøe, K. (2009) Priority-setting in healthcare: a framework for reasonable clinical judgements. Journal of Medical Ethics, 35, s. 488-496.

Bærøe, K. \& Bringedal, B. (2011) Just health: on the conditions for acceptable and unacceptable priority settings with respect to patients' socioeconomic status. Journal of Medical Ethics, 37, s. 526-529.

Cowley, C. (2005) Why Medical Ethics Should Not be Taught by Philosophers. Discourse: Learning and Teaching in Philosophical and Religious Studies, 5, s. 5063.

Creuss, R.L., Creuss S.R. \& Johnston S.E. (2000) Professionalism and Medicine's Social Contract. The Journal of Bone and Joint Surgery, 82, s. 1189-1194.

Den Norske Legeforening $(1961,2002)$ Etiske regler for leger.

Dworkin, R. (1978) Taking Rights Seriously. London: Duckworth.

Eriksen, E.O. (2001) Demokratiets sorte hull - om spenningen mellom fag og politikk $i$ velferdsstaten. Oslo: Abstrakt Forlag.

Fauske, H. (2008) Profesjonsforskningens faser og stridsspørsmål. I Profesjonsstudier, red. A. Molander \& L.I. Tenum, s. 31-53. Oslo: Universitetsforlaget.

Freidson, E. (2001) Professionalism The Third Logic. Chicago: The University of Chicago Press.

Goodin, R.E. (1986) Welfare, Rights and Discretion. Oxford Journal of Legal Studies, 6, s. 232-261.

Gosepath, S. (2005) Equality. I The Stanford Encyclopedia of Philosophy, red. E. Zalta. Lastet ned 2. august 2011 fra http://plato.stanford.edu/entries/equality/

Grimen, H. \& Molander, A. (2008) Profesjon og skjønn. I Profesjonsstudier, red. A. Molander \& L.I. Tenum, s. 179-196. Oslo: Universitetsforlaget.

Hasman, A., Hope, T. \& Østerdal, L.P. (2006) Health Care Need: Three Interpretations. Journal of Applied Philosophy, 23, s. 145-156.

Helse- og omsorgsdepartementet (1999a) LOV 1999-07-02 $\mathrm{nr}$ 63: Lov om pasientrettigheter (pasientrettighetsloven). Lastet ned 23. oktober 2011 fra http:// www.lovdata.no/all/hl-19990702-063.html

Helse- og omsorgsdepartementet (1999b) LOV 1999-07-02 nr 64: Lov om helsepersonell m.v. (helsepersonelloven). Lastet ned 23. oktober 2011 fra http://www.lovdata.no/all/hl-19990702-064.html

Helse- og omsorgsdepartementet (2003) LOV 2003-06-27 $\mathrm{nr}$ 64: Lov om alternativ behandling av sykdom $m v$. Lastet ned 23. oktober 2011 fra http://www.lovdata.no/all/hl-20030627-064.html

Irvine, D. (1999) The performance of doctors: the new professionalism. The Lancet, 353, s. 1174-1177.

Jacobson, N. (2009a) Dignity Violation in Health Care. Qualitative Health Research, 19, s. $1536-1547$.

Jacobson, N. (2009b) A taxonomy of dignity: a grounded theory study. BMC International Health and Human Rights, 9, 3. 
Lian, O.S. \& Skolbekken, J. (2003) Etiske utfordringer ved innføring av ny medisinsk teknologi. Tidsskrift for den Norske Legeforeningen, 123, s. 478-481.

Molander, A. \& Grimen, H. (2010) Understanding Professional Discretion. I Sociology of Professions: Continental and Anglo-Saxon traditions, red. L.G. Svensson \& J. Evetts, s. 167-187. Gotheburg: Daidalos.

Pedersen, R., Akre, V. \& Førde, R. (2009) Barriers and challenges in clinical ethics consultations: The experiences of nine clinicial ethics commitees. Bioethics, 23, s. $460-469$.

Rawls, J. (1993) Political Liberalism. New York: Columbia University Press.

Tanenbaum, S.J. (1993) What physicians know. New England Journal of Medicine, 329, s. $1268-1270$.

Toulmin, S.E. (2003) The Uses of Argument. Cambridge: Cambridge University Press.

World Medical Association (2006) WMA International Code of Medical Ethics. 